
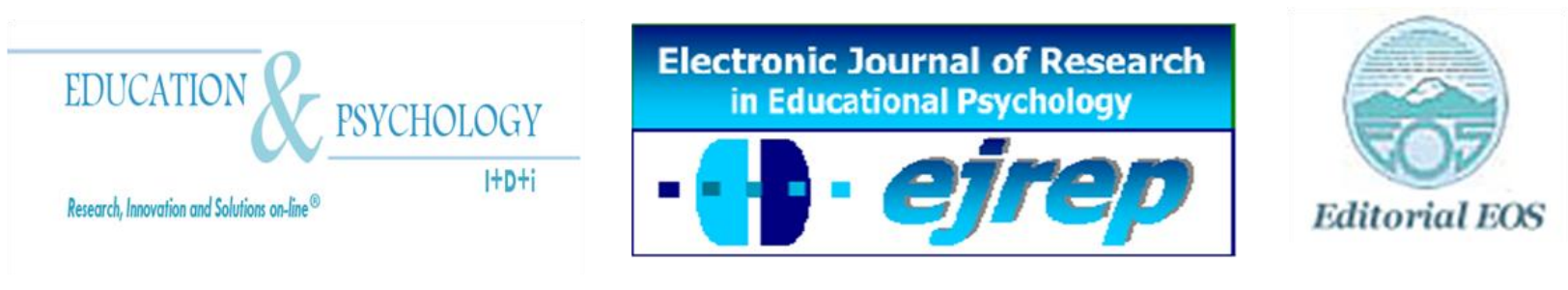

\title{
Teaching in physical education: socialization, play and emotions
}

\author{
Fidel Molina
}

Department of Sociology. Faculty of Education.

University of Lleida

\section{Spain}

Correspondence: Fidel Molina. Faculty of Education. Av. Estudi General, 4. Lleida-25001. Spain. E-mail: molina@geosoc.udl.es

(C) Education \& Psychology I+D+i and Editorial EOS (Spain) 


\begin{abstract}
Introduction. Emotions have not been regarded as very relevant in educational processes, despite early sociologists underlining the importance of feelings in education. The focus of this research is on the teaching of Physical Education at the Primary School level in Spain.

Method. We reflect on the importance of emotions in education from the sociological perspective and present a case study which examines the development of Physical Education through play in centres of primary education. In doing this, we have combined the use of participant observation and sociograms within an ethnographic framework.
\end{abstract}

Results.Through our research, we demonstrate how, by working on emotions in the teaching of Physical Education, we can make a positive contribution to socialisation.

Conclusion.This is possible because it is easier to develop positive emotions - and more effectively channel and constrain negative emotions - when we handle situations of cooperation and competition within a privileged socializing framework such as play.

Keywords: Education, Socialization, Emotions, Conflict Resolution.

Received: 02/20/124

Initial acceptance: $04 / 23 / 12$

Final acceptance: 07/04/12 


\section{La enseñanza en la Educación Física: la socialización, el juego y las emociones}

\section{Resumen}

Introducción. Las emociones no han sido consideradas como muy relevantes en los procesos educativos, a pesar de que los primeros sociólogos subrayan la importancia de los sentimientos en la educación. El objetivo de esta investigación radica en la enseñanza de la educación física en la escuela primaria en España.

Método. Destacamos la importancia de las emociones en la educación desde la perspectiva sociológica y presentamos un estudio de caso en el que se examina el desarrollo de la Educación Física a través del juego en centros de educación primaria. En este sentido, hemos combinado la observación participante y los sociogramas dentro de un marco etnográfico.

Resultados.A través de nuestra investigación, demostramos como, mediante el trabajo sobre las emociones en la enseñanza de la Educación Física, podemos contribuir a una socialización positiva.

Conclusión. Ello es posible porque es más fácil desarrollar las emociones positivas -y canalizar y limitar las emociones negativas- cuando manejamos situaciones de cooperación y de competencia dentro de un marco privilegiado de socialización como es el juego.

Palabras Clave: Educación, Socialización, Emociones, Resolución de Conflictos.

Recibido: $20 / 02 / 12$

Aceptación inicial: 23/04/12

Aceptación final: 04/07/12 


\section{Introduction}

Through micro-sociological analysis, the sociology of knowledge is concerned with the way in which social actors interpret their own actions in everyday activities. In such activities, these actors are active agents and construct the reality into which they have been inserted (Berger \& Luckmann, 1978). As well as the social factors that exist outside schools, the interaction of the actors within the school system is also considered a fundamental element within this process. Through this interaction, the different social actors participate in the construction, selection and management of the knowledge that can then be exchanged within the school. Here lies a fundamental difference with respect to the "old" sociology of education because the role of the teacher in educational change now acquires a fundamental relevance and teachers become researchers rather than being regarded as merely the transmitters of received knowledge (Moll, Amanti, Neff \& González, 1992). Although this idea mainly focuses on aspects relating to "knowledge", we believe that it also opens up new possibilities for integrating elements that are closely related to emotional education and indeed gives greater importance to the study of emotions as an objective within both Physical Education and Sociology.

Our research was based on a case study about how games are played in Primary Education and how they can be relevant and play an important role in bringing out emotions in a more evident way. In our research, we demonstrate how it is possible to make positive contributions to socialisation by working on the emotions in Physical Education. This is so because positive emotions are more easily developed - and negative emotions more effectively channelled and/or constrained - when we are able to work within a privileged socialising framework (such as play and physical education).

\section{Physical (and emotional) Education in the roots of Sociology}

Physical Education is also an object of sociological study as it is a social reality and, moreover, one that attempts to understand and interpret the social process which is Education $^{1}$. The concept of moral education basically corresponds to what Saint-Simon understood to constitute "Education". The educational system has the function of creating the consensus

\footnotetext{
${ }^{1}$ It can be an ideological conception of an orthodox model of physical education that is a particular product of "state reasoning" (Domingos, 2010).
} 
required to maintain social order. According to Lerena (1985: 89-90 y 92), with Saint-Simon positive sociology appears as a sociology both of and for education, within a political project that advocates a system of total education. This educational system should organise homogeneity and diversity and work to legitimate and consecrate these values through a meritocratic system. In this sense, Comte's idea of "education" is inseparably subordinated to the idea of "society". According to Comte, the concepts of the "individual" and "society" may come into contradiction and he sees the former as an abstract product of "education". According to this vision, "education" is a passive process of social adaption and one that subordinates personality (that which is individual) to sociability (society). Education is a central element within this Comtian sociologism as it is an intellectual and emotion-related practice. Saint-Simon and Comte coincide in the belief that education is not only about instruction but also involves feelings and habits. By this logic, it is possible to identify two different types of education: one which is spontaneous and another which is systematic. "Spontaneous education" takes place during the first years of life and within the family, where the mother plays a determining role as a clearly emotional element. In contrast, the educational system also plays a fundamental role in the process of acquiring habits and is essential for maintaining the principles that govern social relations.

According to Durkheim, education is crucial to the process of internalising values and norms, as it plays an important role in solving social problems. However, Durkheim also holds that education synthetically reproduces society and that, as such, it is incapable of totally remedying social problems. For Durkheim, education does not change society; it only reproduces it and is therefore not a factor for change. In stark contrast, functionalists have portrayed education as a factor for change. It therefore seems clear that we move amongst parameters of permanence and change, reproduction and liberation. Whatever the case - and in line with Durkheimian thinking - the role of education in all of this is accessory, although still important. In the training of individuals, the internalisation of common principles makes social cohesion fundamental. According to this viewpoint, education responds to the social needs of a given historical period and human nature is a concept that is arbitrarily constructed to meet the needs and ideals of the members of each specific society. As such, education is used by each society to create its members socially and in accordance with its and their own particular needs. It is the adult generations who impose educative action on the younger generations so that they fit into the workings of society. Even so, Durkheim is conscious of the contradictions of educative practice within the tension between socialisation and individuali- 
sation. In the field of emotional education, the contradictions and complementarities between socialisation and individualisation become clearly evident, but a good case study is required to exhibit this tension and the associated dynamic equilibrium.

However, the scheme adopted by Margaret Mead (1971) calls into question the Durkheimian allegation that educative action is imposed on younger generations by adult generations. She points to societies with what are referred to as "prefigurative cultures" in which it is young people who tend to impose this type of action on the adult generations. This is particularly significant within the emotional fabric of society and - above all - in the expression of emotions: this is explained by generational questions, related to vital cycles and also - and particularly within our own context - to evidently historical, sociological and cultural circumstances. We have learnt to express (or hide) our feelings and emotions in different ways and also to take into consideration - amongst others - such questions as gender, chronological age, socio-professional ethos and status.

Along these lines, Weber does not understand society as an articulated whole -as Marx and Durkheim do-, but instead sees what is social as being constituted through social action. In other words, any human action with meaning and which is directed towards another person or group can be considered social and sociology is a discipline that studies the interpretative comprehension of social action (Guerrero, 1989: 21). It is because of this that that we can now speak of a Weberian sociological theory of schooling, which refers to its structure and functional system. Schooling domesticates and dominates, reproducing the social system and its social order. In this sense, the sociology of education is a continuation of Durkheim's sociology of power and domination, with emotions appearing and being expressed in a channelled way, in line with social conformity.

In the 1970s and 1980s, what has been called the "new sociology of education" proposed a new position that was opposed to functionalism and its macro sociology. This new position saw functionalism as being too determinist in its analysis of social action (and of the human being) and with its perception of the educational system as only an agent for transmitting values and selecting pupils. In contrast, the "new sociologists" highlighted the notion of man as a determined and decisive being. Along these lines, we should also mention the North American interactionist current which emphasises the interactive and intersubjective nature of social life. 
Later, from the 1980s onwards, Cultural Studies began to experience a certain revitalisation. There was very detailed research into the cultural diversity that is present in any modern society, in all of its different social contexts. This provided an alternative to the discourse of cultural uniformity and the homogenisation of the culture of the masses. This cultural diversity was investigated through the processes of cultural creation that give individuals and social groups received messages that are in line with their own cultural codes. This is a basic situation that needs to be understood in order to then understand the current tenets of the Sociology of Intercultural Education and also those of a Sociology of Emotional Education framed within a context of recognised (individual and group) diversity. It could be one of the characteristics of excellent teaching for the diverse student population (Hope King \& Watson, 2010).

\section{Theory into Practice: the case study of socialisation and emotions in the teaching of Physical Education}

Within the interconnectivity between Physical Education, Sociology and Emotions, we glimpse the possibility of integrating a section of the Sociology of Emotional Education, even to protect child athletes in elite Sport, for instance (Weber, 2009). This is closely linked to cultural aspects and close to the ever-better consolidated Intercultural Education, within the now classical field of the Sociology of Education. We look at things in this way because the world of human emotions is sociological and has much to do with socialisation (education); we cannot therefore ignore this in the midst of hyper-rationalist and irrationalist approaches. Reason and "heart" (emotions or feelings) should not be completely separated or seen as opposites, nor should they be considered in isolation.

Socialisation processes are defined by the tension between normative and cultural interiorisation and critical distancing (Dubet and Martuccelli, 1996, pág. 511), or - to put this in another way - between the influence of social institutions on individuals and the modification of the former by the latter. Socialisation analysis is the study of the processes through which social structures influence individual conduct and transformation society, regardless of whether or not these are the result of the deliberate action of individuals; it therefore has different interpretations according to different sociological paradigms. According to Durkheim, socialisation perpetuates and reinforces the need for cultural homogeneity amongst the members of a given society. Simmel, in contrast, defines society as a complex of socialised individuals who exhibit social conformity but also as the sum of the different ways of interrelat- 
ing through which society emerges; in other words, we are the products of society but also members of society. Other sociologists, including Marx, Weber and G. H. Mead, defend the notion that the individual human being is a result of specific historical circumstances that, at the same time, and as a result of human action, modify social institutions. When we consider the subject of the emotions, it is also necessary to refer to the contributions of Freud and his psychoanalysis. This upholds that culture implies coercion and that - as a result - the goal of education is to teach individuals how to control their impulses.

Bernstein, on the other hand, defines socialisation as a more or less arbitrary mechanism whose job is to transform what is cultural (what has been socially constructed) into something natural. Other authors, harking back to the idea of a tension between cultural and normative interiorisation and critical distancing, have collected together the different theories of socialisation and divided them into two large blocks that follow these two basic postulates: a) the first, which is the closer to modernity, affirms the reversibility of the subjectivity of the actors and the objectivity of the system, stressing that socialisation is defined as normative and cultural interiorisation; b) in contrast, the second, which is closer to the tenets of postmodernism, appears to be more sensitive to cultural and social heterogeneity, favouring the notion of the distancing of individual activity and the separation of the actor from the system (Dubet and Martuccelli, 1996: 511 and following pages) We therefore find ourselves in situations that involve both the individual and society. In this sense, within processes of socialisation, we can distinguish both the individual and social possibilities of the emotions: they lie between what is biological and cultural and between what is innate and learned. The sociological prism becomes even more evident when we refer to the expression of emotions.

Framed by the previously mentioned theories and models, the case study presented and discussed in this research will throw light on the types of strategies and methods that are currently used within the Spanish school system in order to promote emotional education. The case-study technique is indeed useful in this respect. It implies the collection of data in order to study a given phenomenon within a real life context using multiple sources of information and it always refers to a real situation, which is analysed within its own context (Stake, 1994 and 1995). However, it does not constitute a mere sample: instead, it offers a way of enriching existing theory and making new generalisations or "analytical generalisations"; in the words of Yin (1984), "thereby enabling us to do some justice to the wealth and complexity of social situations" (Collerette, 2001: 102). Amongst the different types of case study that are possible, the one on which this article is based could be classified as 'multiple' and 'instrumental', 
as it provides a typical situation in which to verify elements of socialisation within the framework of sociological theory and Physical Education (Molina, 2002 and 2007). Through the 'multiple, instrumental case study' it is possible to identify the factors that contribute to the success of teaching Physical Education (in relation to emotions, Lavega et al. 2011).

The focus of this study (and the associated fieldwork) is the teaching of Physical Education at the Primary School level in Spain (and more specifically, in two schools in Catalonia).

In our research, we reflect on the importance of the emotions in education viewed from the sociological perspective and, more concretely, through a case study relating to the development of Physical Education through play in centres imparting primary education. We combine participant observation and use of the sociogram within an ethnographic framework. We value individual idiosyncrasy, but also emphasise the importance of the group and of the culture in which socialisation takes place. In our research we show how, by working on the emotions in Physical Education, we contribute positive elements to socialisation. This is because positive emotions are more easily developed and negative emotions are more easily channelled and constrained when we consider situations of cooperation and competition within a privileged socialising framework, such as that of play.

According to Durkheim, homo sociologicus is passive because he is a product of the different social causes that would cause a certain type of behaviour. This implies a certain type of sociological determinism: sociologism, which tries to explain all human phenomena in group terms. However, this Durkheimian line is opposed to other extra-social or evolutionist determinisms, because for Durkheim, it is social fact that allows us to explain what happens socially. Within this framework, education is a social and sociological fact, but emotions also end up becoming the object of sociological study, between the biological, educational and sociological coordinates. Although social research should be principally based on empirical analysis, in a positivist line in which what matters are observable facts (and for Durkheim, social facts must be treated as things), evidencing the characteristics of objectivity and regularity will permit their scientific study. This can also be applied to a qualitative methodology, such as participative observation, - with ethnography as an example - which has proved indispensable in our research. We combined participant observation with the use of informants, adopting an ethnographic framework and applying an empirical analysis of the observable facts: the emotions expressed through play. 
The study was carried out with students aged between 9 and 10 years old (studying the $3^{\text {rd }}$ course of primary education $)^{2}$ whose behaviour was observed in physical education classes and also in classes of other subjects taught in the classroom. The basic objective was to observe the emotions exhibited by the students in each situation and to compare the resulting differences (Koekoek, J., Knoppers, A. \& Stegeman, H., 2009) ${ }^{3}$. The initial hypothesis was a double one: on one hand, that students exteriorise more emotions in physical education classes than in their normal classes and, on the other, that positive emotions are the ones most repeated in physical education sessions.

We registered our observations using the table presented in the annex ${ }^{4}$, in which a differentiation was made between positive and negative emotions and the types of behaviour associated with each type of emotion are registered. We also recorded the intensity of the emotions demonstrated, which were scored from 0 (absence of emotion) to 3 (high intensity emotion).

Amongst the results obtained, we should highlight the fact that $82 \%$ of the emotions expressed were observed in the physical education sessions, while only $18 \%$ were observed in the classroom sessions. Similarly, of the emotions expressed in the physical education sessions, $66.5 \%$ were positive and $33.5 \%$ negative or ambiguous.

The results relating to this last consideration were compared with those from a similarly organised study ${ }^{5}$ that had explored cooperative situations and included a sociometric analysis of a group of students who were also studying the $3^{\text {rd }}$ year of primary education ( 9 to 10 years old). In the study, the emotions observed in cooperative situations also varied, but they followed a series of main trends associated with greater happiness and welfare, humour and friendship, with the latter being specifically associated with trust in colleagues and developing a clear empathy. Even so, even in situations of cooperation, negative emotions were generated in association with competitiveness, with the most significant of these being anger and sadness (and, from time to time, a certain degree of anxiety). Within this context, the con-

\footnotetext{
${ }^{2}$ The field work and the analysis deriving from it were carried out by G. Trabal, with whose help the results were discussed within the framework of the Practicum of Teacher Training Degree focusing on Physical Education, 2009).

${ }^{3}$ Exploring how children express their experiences, thoughts, and feelings is generally important within Physical Education.

${ }^{4}$ The table was created and discussed the work group on Education, Sport and Emotions (Agulló, M.J.; Filella, G.; Lacasa, E.; Lagardera, F.; Lavega, P.; Mateu, M.; Molina, F.; Soldevila, A.) of INEF (National Institute of Physical Education) and the Faculty of Education of the University of Lleida (Spain).

${ }^{5}$ In this case, the field work was carried out by J. Andueza, at a school in Lleida, within the framework of the Practicum of Teacher Training Degree focusing on Physical Education and a doctoral thesis (2009 and 2011).
} 
cept of emotion has a certain relationship with sociometric status, above all in its more negative aspects, and particularly with respect to students who are not taken into consideration when it comes to participating in games (who can suffer silent discrimination) and who consequently show anger and frustration. In situations that were clearly ones of cooperation, $87.5 \%$ of the emotions observed were positive (above all relating to happiness and welfare) while $12.5 \%$ were negative (basically anger). In contrast, in situations of competition, only $20 \%$ of the emotions observed were positive (mainly happiness) while $80 \%$ were negative (mainly anger and sadness). Yoncalik (2010) states that students are mostly in seek of attention and they generally want to be first and best, which are described as the most common unwanted student behaviours described by the Physical Education teachers.

In fact, as Maturana (2001) points out, healthy competition does not exist ${ }^{6}$ because $^{-}$ within the human condition, competition tends to basically consist of opposing and negating other people:

"Observe the emotions involved in sports competitions. In them, there is no healthy coexistence because the victory of one is born out of the defeat of the other, and the most serious thing is that, under the discourse that values competition as a social good, one does not see the emotion that constitutes the praxis of competing, and which is what constitutes the actions that deny the other" (Maturana, 2001, p. 6)

\section{Conclusions: the sociology of homo sentimentalis in Physical Education}

Physical Education is an invaluable vehicle for emotional education because, as we have already seen, it facilitates the expression of emotions and these tend to be mainly positive. Homo ludens tends to be more emotional than the normal homo sapiens sapiens. As a result, we should therefore subtly qualify Darwin's affirmation that the expression of emotions has an innate and universal base. Instead, we must consider that we rapidly develop cultural contributions on this base and that these are shaped by the type of socialisation carried out within each cultural group.

The homo sentimentalis (see Illouz, 2007) reminds us of the role of the emotions in the very institutionalisation of society and social action: this was clearly seen by sociologists like Weber (the role of emotions, such as anxiety, in economic action) and Marx (the concept of

\footnotetext{
${ }^{6}$ The same author pointed out that competition is a cultural and human phenomenon and is not related to biological factors.
} 
alienation as a loss of reality in relation to matters connected with the object) and in Simmel's story about the metropolis, which includes an account of emotional life. In a certain way, when Durkheim understands solidarity as a series of emotions that link social actors to the central symbols of society, he is underlining the emotional base to socialisation, because symbolic classifications (cognitive entities) have this base. According to Illouz (2007), the emotions are social relations and cultural meanings that are inseparably fused together, and this fusion confers the capacity to impart energy for action. It is also possible to find emotional hierarchies, because some emotions (and their expression) are more valued than others in certain cultural settings... and here, education (socialisation) again plays a very important role. According to the same author, it has also been traditional to recognise a conventional division between an unemotional public sphere and a private sphere that is full of emotions.

Now, we encounter a change in the paradigm for interpreting the global and globalised world and this paradigm is cultural (Touraine, 2005). We essentially find ourselves in a new culture of emotivity (Illouz, 2007) in which the interior private "I" has a much more public representation, combining the aspiration to self-realisation with the affirmation of emotional distress.

In another sense, when we establish the methodological need to record the expression of emotions, we can - as Halbwachs (see Fleury, 2004) did - understand that this expression has much to do with representation and ritual or ritualised practices. In this sense, our research holds a double value (methodological and conceptual), helping us to overcome the classical dichotomy between rites and emotions or between expression and representation, within the ludic framework of playing and the ritual of play.

Furthermore, let us not forget that Physical Education is a form of practical intervention that influences the conduct of its participants in line with implicit or explicit educational norms (Parlebas, 2003). In this sense, physical education also has much to do with cooperative and competitive approaches, which also generate different feelings and emotions. We shall therefore need to evaluate, in educational terms, which values we are socialising and which emotions we are consolidating and whether we should promote cooperative games or competitive sport and, in any case, how we should approach this subject and manage the resulting conflict. This may prove either enriching or devastating, depending on how it is approached and managed. 


\section{Acknowledgements}

The original design for the subsequent research was organised through the European Union's "Socrates Intensive Programme "Teaching and Diversity", TeDiv" (27954-1-2005-BEERASMUS-IPUC-2; 2007).

This article is the product of theoretical reflection and field work carried out within the framework of research entitled "Intercultural coexistence in Primary and Secondary Education in Catalonia: the present and future of inclusive education". This formed part of the ARIE-07 and ARIE-08 Programme, through which the AGAUR (Government of Catalonia, Spain) provides support for research (in this case, Projects 2007and 2008/2009 ARIE-00006) and the project "Stories of a Possible Europe" (Europe for Citizens Programme of the European Union, Project N ${ }^{\circ}$ CP-2008-045) which was developed between 2008 and 2010 (within which theoretical reflections and research approaches also continued in 2011, at the CEJEM Centre for European Juridical Studies and Mediation- research institute of the University of Lleida, which has made an economic contribution to the cost of translating this work into English).

\section{References}

Bericat, E. (2000). La sociología de la emoción y la emoción en la sociología. Papers. Revista de Sociología, 62, 145-176.

Bisquerra, R. (2003). Educación emocional y competencias básicas para la vida. Revista de investigación educativa, 21 (1), 7-43.

Buscarais, M. R. (1997). La formación del profesorado en educación en valores. Bilbao: Desclée de Brouwer.

Cascón, F. (2000). Educar para la paz y la resolución de conflictos. Barcelona: Cispraxis.

Collerette, P. (2001). Estudios de casos. In A. Muchelli (Coord), Diccionario de Métodos Cualitativos en Ciencias Humanas y Sociales (p. 102-106). Madrid: Síntesis.

Domingos, N. (2010). Building a motor habitus: Physical Education in the Portuguese Estado Novo. International Review for the Sociology of Sport, 45 (1), 23-37. 
Dubet, R. \& Martuccelli, D. (1996). Théories de la socialisation et definitions sociologiques de l'école. Revue française de sociologie, 37, 511-535.

Elias, N. (1982). The Civilizing Process. Oxford: Blackwell.

Fleury, L. (2004). Una sociología de las emociones. Historia, antropología y fuentes orales, $32,99-122$.

Freire, P. (1973). ¿Extensión o Comunicación? La concientización en el medio rural. Madrid: Siglo XXI.

Harre, R. \& Jones, R. F. (1986). The Social Construction of Emotions. Oxford: Blackwell.

Harris, P. (1989). Children and emotion. Cambridge University Press: New York.

Hope King, S. \& Watson, A. (2010). Teaching Excellence for All our Students. Theory into Practice, 49 (3), 175-184.

Illouz, E. (2007). Cold Intimacies: The Making of Emotional Capitalism. London: Polity Press.

Jares, X. R. (2001). Educación y conflicto. Guía de educación para la convivencia. Madrid: Popular.

Koekoek, J., Knoppers, A. \& Stegeman, H. (2009). How Do Children Think They Learn Skills in Physical Education?. Journal of Teaching in Physical Education, 28 (3), 310332.

Lavega, P., Filella, G., Agulló, M. J., Soldevila, A., \& March, J. (2011): Understanding emotions through games: helping trainee teachers to make decisions. Electronic Journal of Research in Educational Psychology, 24, 9 (2), 617-640.

Maturana, H. (2001). Emociones y lenguaje en educación y política. Santiago de Chile: Dolmen Ensayo.

Mead, M. (1970). Culture and Commitment. Gardin City: Doubleday.

Molina, F. (2002). Sociología de la Educación Intercultural. Buenos Aires: Lumen.

Molina, F. (2007). Socialization, glocal identity and sport. European Journal for Sport and Society, 4 (2), 173-181. 
Moll, L., Amanti, C., Neff, D., \& González, N. (1992). Funds of knowledge for teaching: using a qualitative approach to connect homes and classrooms. Theory into Practice, 31 (2), 132-141.

Navarro, V. (2002). El afán de jugar. Barcelona: Inde.

Parlebas, P. (2003). Elementos de sociología del deporte. Málaga: Unisport.

Stake, R.E. (1994). Qualitative case studies. In N.K. Denzin \& Y.S. Lincoln (Ed), Handbook of Qualitative Research (p. 443-466). London: Sage.

Stake, R. E. (1995). The Art of Case Study Research, Thousand Oaks (Ca): Sage.

Touraine, A. (2005). Un nouveau paradigme. Paris: Librairie Arthème Fayard.

Weber, R. (2009). Protection of children in competitive sport: Some critical questions for London 2012. International Review for the Sociology of Sport, 44 (1), 55-69.

Yin, R. K. (1984). Case study research. Design and methods. London: Sage.

Yoncalik, O. (2010). Students' misbehaviors in physical education lessons: a sample from Turkey. Electronic Journal of Research in Educational Psychology, 8(1), 59-86. 
ANNEX

IDENTIFIYING DATA

\begin{tabular}{|l|l|l|l|l|}
\hline Name & Age & Gender Man Woman & Course & Subject \\
\hline
\end{tabular}

\begin{tabular}{l}
$\begin{array}{l}\text { Emotion } \\
\text { Play } \\
\text { Situation }\end{array}$ \\
\hline $\mathbf{1}$
\end{tabular} Happines $\begin{aligned} & \text { Pumour } \\
& \mathbf{1}\end{aligned}$

\section{$\underline{\text { Positive Emotions }}$}

Happiness: enthusiasm, euphoria, excitement, contentment, entertainment, pleasure, gratification, satisfaction, whim, ecstasy

Humour: smile, laugh

Friendship: affection, esteem, sympathy, empathy, acceptance, cordiality, trust, amiability, affinity, respect, devotion, infatuation

Welfare: happiness, tranquillity, peace, placidness, satisfaction,

\section{Negative Emotions}

Anger: anger, rage, nastiness, hate, fury, indignation, resent, exasperation, tension, excitation, agitation, irritability, hostility, violence, annoyance, jealousy, envy, impotence,

Fear: fear, horror, panic, terror, anxiety, fright, phobia

Anxiety: angst, desperation, uneasiness, stress, worry, craving, consternation, nervousness

Sadness: depression, frustration, deception, distress, sorrow, pain, grief, pessimism, melancholy, loneliness, reluctance, disgust, worry

Shame: blame, shyness, insecurity

Aversion: hostility, contempt, antipathy, resentment, rejection, suspicion, repugnance, repulsion 